\title{
THE EFFECTIVENESS OF MARKETING AND THE DEVELOPMENT OF MARKETING COMPETENCE AS A FACTOR IN IMPROVING THE EFFICIENCY OF SPATIAL INTERACTION
}

\author{
Ukrainian State University of Chemical Technology, Dnipro, Ukraine
}

\begin{abstract}
In the work it is revealed the content of marketing competence as the basis for the concept of ensuring management of effective marketing, as well as the basis for creating sustainable competitive advantage based on the provisions of the paradigm of $\mathrm{G}$. Bagiyev and $\mathrm{H}$. Hokkanson that is the concept of spatial interaction marketing. The components and sources of additional marketing competence are shown. It is clarified that in the global information society, marketing management concepts in the global economy are being developed in close cooperation with modern concepts and approaches in the field of management, marketing, financial analysis, system analysis, computer science and modeling of economic processes in the geo-economic space. According to the results of work, the status of the methodology and the system of performance management of marketing was developed. An illustrative model "Sources of acquiring additional marketing competence", as well as the improvement of the concept model of Y.N. Solovyova "Interdependence of components of marketing competence".
\end{abstract}

Keywords: marketing, marketing of spatial interaction, competence, marketing competence.

DOI: $10.32434 / 2415-3974-2018-8-2-110-119$

\section{Formation of the problem}

Modern economic conditions in the global economy and in Ukraine, the processes of globalization and the acceleration of the markets' development, technologies, social and political factors of the information society development, crisis phenomena in various regions and sectors of the world economy require new approaches and management methods. Today, the basis of the successful work of enterprises, firms in the business sector of the economy is market-oriented management based on advanced methods and technologies of marketing management using information and communication technologies and systems.

The complexity of marketing management at the beginning of the XXI century has increased dramatically. Traditional methods in this area need to be complemented with approaches that implement effective feedback in the management cycle based on regular measurement and analysis of indicators reflecting the performance of marketing activities at all levels of management, indicators reflecting the state of the external environment, and the development of marketing competencies efficiency of spatial interaction. The management of an enterprise (firm, company) is based on the development and implementation of value-oriented marketing strategies, while value-oriented marketing strategies within the economic space and having a base in the form of marketing competencies are aimed at defining various relationships and developing growth strategies as well as developing stable relations with target groups of consumers within the framework of the marketing ideology of expanded interaction (according to G. Bagiyev, H. Hokanson).

The concept of interaction marketing involves the end-to-end optimization of all resources and activities in managing the exchange processes between market participants. Following the principles of marketing interaction leads to the fact that all employees of the company are involved in the process of forming and developing of long-term mutually beneficial relationships with customers [1]. The practical implementation of interaction marketing largely depends on the accuracy of the mutual interpretation of the needs and capabilities of the partners. According to G.L. Bagiyev, the marketing of interaction increases the importance of the personality and personal contacts in the system of marketing communications [2].

In fact, the efficiency of information sharing

(C) Dubnitsky V.I., Kozhevnik Yu.V., Dotsenko A.E., 2018 
depends both on its source: it must have information, have a desire to share it and the ability to formulate it, and on its recipient, who must be able to perceive it, interpret it correctly and use it in its work. In this regard, the advancement of the marketing concept of interaction in the list of the highest priority has increased attention to the factor of marketing competence. Marketing competence is formed on the basis of information about the needs of partners, actions of competitors, trends in the macroenvironment due to interactions within the company and beyond its limits. Marketing competence becomes an integrated factor of marketing success, since it is a resource of any market interaction.

In an enterprise management system, marketing performance management plays the most important role, defined as activity to achieve marketing goals in the most efficient way in the conditions of optimal use of resources: marketing performance management involves the formulation of a marketing strategy in the form of a system of measurable strategic goals, initiatives and key performance indicators, and through regular measurement of tactical and operational values of these indicators and the values of environmental indicators, the plan-factor analysis, modeling, forecasting, planning and budgeting that allows to carry out management and helps to perform the goals and results, as well as to adjust the targets in accordance with the dynamics of changes in the external and internal environment. Being an integral part of marketing management and corporate performance management, this area is new, relevant and popular in practice.

The main issues are the effectiveness of product innovations management, especially the management of marketing performance in the electronic market on the Internet, as well as the impact of a transitive economy on the management of marketing performance with regard to real situation in Ukraine. Relevant and practically important are methodological approaches to the design of a marketing performance management system, including methods for identifying strategic objectives and key performance indicators that reflect a valueoriented marketing strategy, as well as an informational infrastructure to ensure marketing performance management.

\section{under reasearch \\ Analysis of scientific publications on the theme}

Issues of marketing performance management related to the development of the theoretical foundations for evaluating the results of marketing activities were studied by such foreign scientists as T. Ambler, P. Dickson, V. Kumar, J.J. Lambin, D. Norton, D. Shet, G.L. Bagiyev, A.A. Braverman, O.K. Oyner, I. Kitova. The problems of holisticoriented management and marketing were developed in the works of E.V. Krikavsky, S.N. Illyashenko,
T. Copeland, E. Helferd, J. Stern. The theory and practical aspects of corporate performance management and marketing competence were developed in the studies of P. Drucker, S.N. Bruskin, G.L. Bagiev, A.N. Lityagin, M.I. Belyavtseva, N.B. Zavyalova, Y.N. Solovyova, A.A. Dligach, O.A. Shulgi, H. Mefert, V. Fritz.

The aim of the work is to develop the theoretical and methodological principles of theory of marketing and marketing competence performance management as the basic factors of efficiency and spatial interaction.

\section{Presentation of the main research material}

The performance in the most general form means the fulfillment of plans, goals and their transformation into concrete results, which are compared with the defining standards, norms and/ or predetermined values of these or those result indicators. In the new economy, there is an acceleration of various changes and all business processes of an enterprise (company, firm), therefore a comprehensive accounting of all departments and all activities is required. Especially those that affect the future market position of the enterprise (firm, company) and the growth of its value.

In the global information society, in the global economy, marketing management concepts are developed in close cooperation with modern concepts and approaches in the field of management, financial analysis, computer science, system analysis and modeling. Marketing strategies in a global economy and economic space focused on value, aimed at identifying market opportunities and developing growth strategies, as well as developing marketing competencies as a tool for implementing strategies for achieving sustainable relationships with target groups of consumers.

Competence is accumulated by an individual, team or organization knowledge, used to develop new knowledge, methods and technologies and manifested both in practical activities and in communications receives particular importance when building partnership, relationships in a changing, turbulent external environment [2]. In the competence can be identified cognitive, behavioral, motivational, value-semantic aspects, i.e. there must be a readiness to exercise competence [3]. The value aspect of competence justifies the inclusion in its composition the ability to spread new knowledge developed by one company throughout the value chain. The ability to transfer part of their knowledge, integrate them within the framework of cooperation in market interaction is necessary for the organization for effective collaboration. In particular, here we can talk about the commercialization of new technical ideas, the formation on their basis of new consumption standards.

The process of extending the competence of a 
leading innovative company to its subcontractors and partners becomes more intense within clusters. The fact that companies in a competitive cluster are concentrated in a specific geographic area is explained not only by lower logistics costs, but also by the possibility of implicit knowledge transfer with their constant interaction.

The idea of cluster orientation of the modern economy has been reflected in the development of interaction marketing, clarifying it in the marketing concept of spatial interaction. Spatial interaction marketing is the process of formation, development and optimization of the spatial hierarchy of social and economic relations between economic entities regarding the search, production, distribution and consumption of unique values, taking into account the factors of development the needs, rational use of resources and social development [4,5]. Marketing space is seen as a set of interrelated relationships about the creation, distribution and use of unique values. In this space, conditions are created for the formation of marketing competence such as knowledge that ensures the long-term competitiveness of the subject of market relations by finding a match between possibilities of creating an offer and the demands of the partners. It includes individual and collective knowledge used by an enterprise or firm to solve marketing tasks, as well as information on the basis of which this knowledge is built due to the intelligence, motivation and intuition of employees.

The company's high level of marketing competence allows to recognize trends and structure situations in the external environment, to anticipate the diverse consequences of its actions, and to influence the formation of future market conditions. In a broader sense, marketing competence can be considered as a special form of public consciousness, i.e. the form of reflection in the minds of people of market interaction, which arose in the course of practical activity in the role of sellers and buyers. Marketing competence as a specific form of public consciousness begins to develop with the increasing complexity of global competition, increasing the size of enterprises, increasing the role of symbols in modern communication, increasing the relationship between the functioning of spatially delineated clusters and the quality of life in a particular territory.

The importance of the analysis and purposeful formation of the market competence of a company is due to the fact that marketing knowledge, i.e. knowledge of the markets, the needs of partners in the interaction and their respective abilities of the company are distributed almost throughout the organization. Marketing projects are flexible, complex, requiring the generation of ideas, joint synthesis of decisions and action plans based on information analysis. At the same time, there are acute problems of separating valuable information from poorly useful among large amount of available information, as well as formalizing and recording valuable knowledge of the most competent marketing specialists in information systems. Competence is a particularly valuable resource and the basis of sustainable competitive advantage in terms of spatial interaction, because:

- whereas new product lines or even a new technology can be copied at a greater or lesser cost, competence cannot be copied, since it has the ability to reproduce and develop. Competence is an asset, the joint use of which by all the interacting companies allows to increase it significantly. A single company outside the spatial network of interaction usually cannot repeat the process of forming and developing competence;

- competence cannot be acquired in the market. Although it is possible to attract individual experts and to adjust the flow of new information, collective competence created by the interaction of individual knowledge and skills is unique;

- creating of competence takes a long time, so competitors cannot develop it instantly due to budget growth and attracting new employees; competence is able to develop faster due to the presence of a certain critical mass of some resources or a combination of them. For example, a wide range of in-house sales facilitates marketing research into customer needs and speeds up the introduction of new products;

- analysis of the marketing competence of the company is difficult for competitors in contrast to, for example, advertising activity.

Marketing competence implies a vision of the prospects for expanding the potential of markets and knowledge of the possibilities of attracting the resources of business partners to shape and meet demand. The high level of development of marketing competence is manifested in the fact that the company in the process of interaction with customers has the opportunity either to reorient their interests and potential demand to the market of goods offered by the company, or to reorient the use of its network resources to reproduce and meet the prospective needs of customers. This is manifested in the progressive power of the marketing influence on the efficiency of business processes in a market economy, its role as foresight technology [3, p. 389].

Collective marketing competence is made up of the best leading individual competencies that manifest themselves in the activity, including the interaction between employees of one or more companies. Any company has marketing competence, however, the degree of its development and the effectiveness of the manifestation may have significant differences. Marketing competence is formed gradually as a result of purposeful selection 
and accumulation of information and is manifested in the improvement of both the marketing activity and the organizational structure of inter-company interaction.

All components of marketing competence are closely interrelated (Fig. 1). The interaction of individual knowledge and skills of marketers determines their collective knowledge, which, in turn, affects the behavior of other employees of the company, communicating with business partners, and models of interaction with the subjects of the marketing network. Marketing software supports the workflows of employees of the marketing department, as well as interaction with partners. The experience of interaction with other enterprises on the market is reflected in the databases, which, in the case of their automation, are managed by the appropriate software. In Fig. 1 are marked feedbacks in the system of marketing competence. Individual knowledge of each employee is enriched through the exchange of experience with colleagues, as well as through the study of information accumulated in databases. In various ways, the marketing department takes into account, in its decisions and actions, the signals of the market, transmitted by part-time marketing specialists, and the wishes and suggestions of the cooperating enterprises.

However, Fig. 1 does not fully reflect the whole process and sources of formation of marketing competence, since, first of all, it is built around the internal factors of marketing competence without taking into account the fact that competence can be developed through the acquisition of information, in particular, from universities and training centers, and consulting firms and marketing research agencies, software and database providers, that is, all participants in spatial interaction. Sources of attracting additional marketing competence are shown in Fig. 2.

Thus, by type of carrier, the following components of marketing competence can be distinguished:

- competence belonging to a specific employee of the enterprise;

- codified competence reflected in the databases and documentation of the enterprise (enterprise standards, marketing research reports, databases of customers and suppliers, tender documentation, etc.);

- software;

- codified competence registered in the manner prescribed by the law (trademarks);

- internal collective competence reflected in the business processes of the enterprise;

- external collective competence, shared with partners in the value chain and manifested in interaction with them.

Marketing competence plays a decisive role to ensure the competitiveness of the company, since, if it is insufficiently developed, the flexibility and resource capabilities of the industrial financial and other functions of the company remain unclaimed. It plays a leading role in providing the enterprise with external information resources, i.e. in the

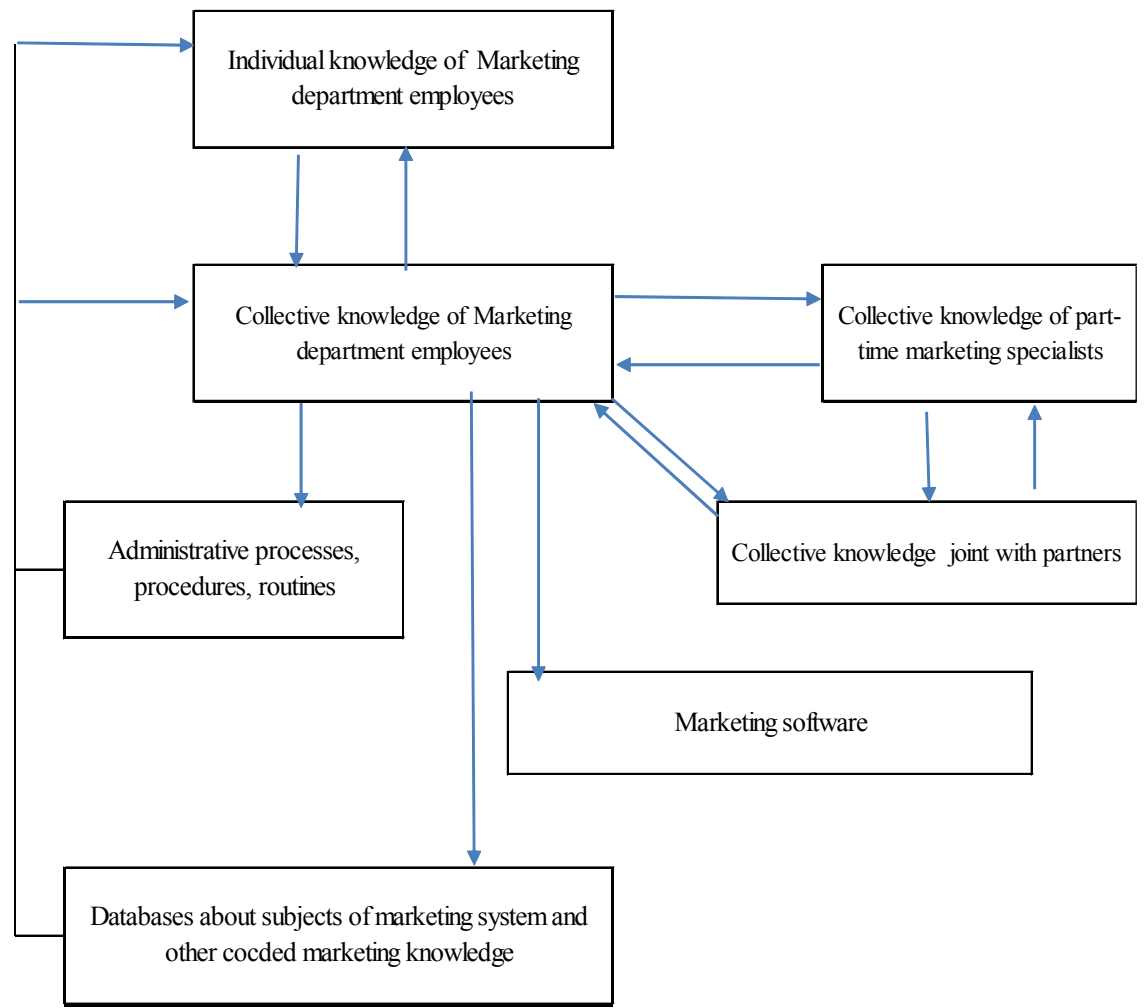

Fig. 1. The interdependence of the components of marketing competence [3, p. 389] 


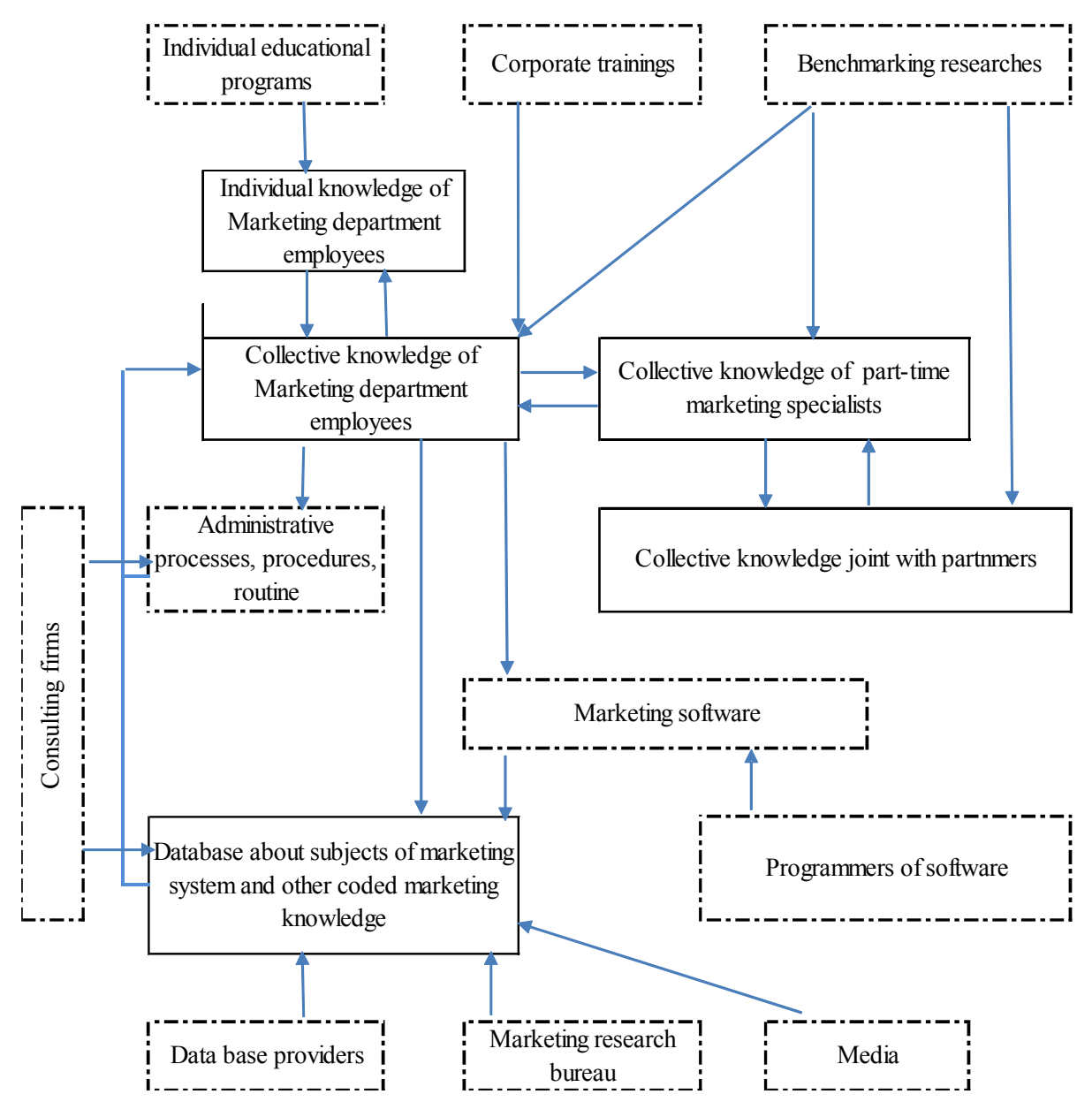

Fig. 2. Sources of acquisition of additional marketing competence

development of collective competence, jointly with partners in the value chain. Consequently, the development of marketing competence should be ahead of the development of other types of competence and determine the directions of their improvement in the company, focusing on the concept of spatial interaction marketing.

It is necessary to highlight the closely interrelated directions of innovative development of concepts and methodical approaches to marketing management in the geo-economic environment: the mutual influence of marketing and strategic management; development of the concept of marketing competence and the concept of marketintegrated management; development of the concept of performance management (Performance Management - Performance Marketing), as well as the development of integrated information systems.

Marketing performance management is called the activity to achieve targets in marketing with optimal use of resources. Marketing performance management involves the formulation of a marketing strategy in the form of a system of measurable strategic goals, initiatives and key performance indicators. With the help of regular measurement of achieved in the process of tactical and operational management values, and the values of environmental indicators, plan-factor analysis, modeling, forecasting, planning and budgeting, it is possible to carry out management that contributes to the achievement of goals and results, as well as adjust goals according to changes in the external and internal environment, taking into account large volumes of business information [6].

Marketing performance management includes processes (such as modeling, forecasting, planning, budgeting, monitoring and analyzing performance indicators and environmental indicators), methods defining some processes, metrics for measuring goal achievement, as well as information systems supporting these processes. Marketing performance management does not deny or replace the existing methods of marketing planning and management, but creates a mechanism that allows the company to use them effectively in practice. The authors consider it to be important in the framework of the marketing performance management process to apply the concept of value-oriented management and value-oriented marketing, where it is appropriate.

Cost-oriented marketing provides a holistic, 
logically consistent approach to defining strategic goals and building an appropriate system of indicators, highlighting the main goal of a commercial firm increasing the expected amount of its discounted cash flows in the short and long term, provides a single quantitative approach for evaluating decisions . Marketing performance management reflects the dialectical interrelation of the concepts "whole" and "part" in the aspects of strategic policy and marketing strategy, as well as in all areas of operational marketing, ensuring the implementation of this strategy. Marketing performance management is an integral part of the marketing management system in the organization, as well as an integral part of corporate performance management, ensuring targeted management of the company and the implementation of its market-oriented strategy. Therefore, the authors relate this concept to such areas as corporate planning, forecasting and budgeting.

The most important part of marketing performance management are also the methods of its expression through the integrated performance indicators of the company, primarily through the measurement of its cash flows. According to the authors, the concept under consideration includes as an integral part the performance management of related phenomena, such as customer relations, staff work in marketing, development of corporate culture, training and growth, development of organizational and IT infrastructure, quality, innovation, and more. An important aspect of marketing performance management is the objective need for timely receipt, processing and analysis of large amounts of information, which is impossible without a modern information infrastructure. Effective marketing management of a company today relies on the construction and use of an integrated marketing information system, which is part of a corporate information system and combined with external information systems and data sources. Informational infrastructure for ensuring management of marketing performance is part of an integrated marketing information system [6].

The authors, in accordance with modern approaches to the methodology from the point of view of system analysis, proposed a methodical approach to managing effective marketing using the provisions of the concept of marketing competence in the context of spatial interaction.

The logical structure of marketing performance management includes the object and the subject; forms of activity, purpose, objectives, means, methods, processes and results. The object in marketing performance management is the organization of various industries with large and medium-scale operations, having commercial interests in the implementation, as well as product management: materials (goods) and intangibles (services, intellectual and virtual products). The subject is the managers and other practitioners of the abovementioned organizations that carry out marketing performance management activities. The subject is a holistic process of managing the performance of the marketing object. The purpose of marketing performance management is the implementation of the organization's strategy and goals in the field of marketing and in the most efficient way in terms of optimal use of resources.

The main objectives of marketing performance management:

- transferring of the marketing strategy into concrete, measurable formulations of goals and measures, reorientation of financial indicators to the evaluation of the company;

- improving the overall understanding of the mission, vision and strategy of the company by its employees, combining the efforts of different departments through understanding the interrelationships between the goals, increasing the motivation of employees in achieving the target values of indicators within the framework of the system and responsibility for achieving the planned values of key indicators;

- improving the planning, monitoring and control process, including through regular analysis of environmental factors, the company's position in the market, the use of forecasting tools, scenario analysis, etc.;

- improving the process of regular specification and alignment of goals and corresponding key marketing performance indicators in accordance with the dynamics of market changes and the competitive position of the company;

- improving the system of internal and external reporting;

- reengineering and automating the core business processes of marketing performance management and processes that influence the achievement of strategic goals.

Forms of activities of marketing performance management include: projects and programs in the field of marketing performance management; technologies of marketing management and performance management, which include: management technology (concepts, methods, processes, metrics, etc.) and information technologies (systems of Corporate Performance Management and Business Intelligence, ERP-systems, CRM-systems, corporate portals etc.). Means and tools for managing marketing performance include: material instruments and tools (for example, instruments for measuring material flows based on barcode scanning or RFID, instruments for conducting marketing research); information software and hardware complexes, including databases and data warehouses, information 


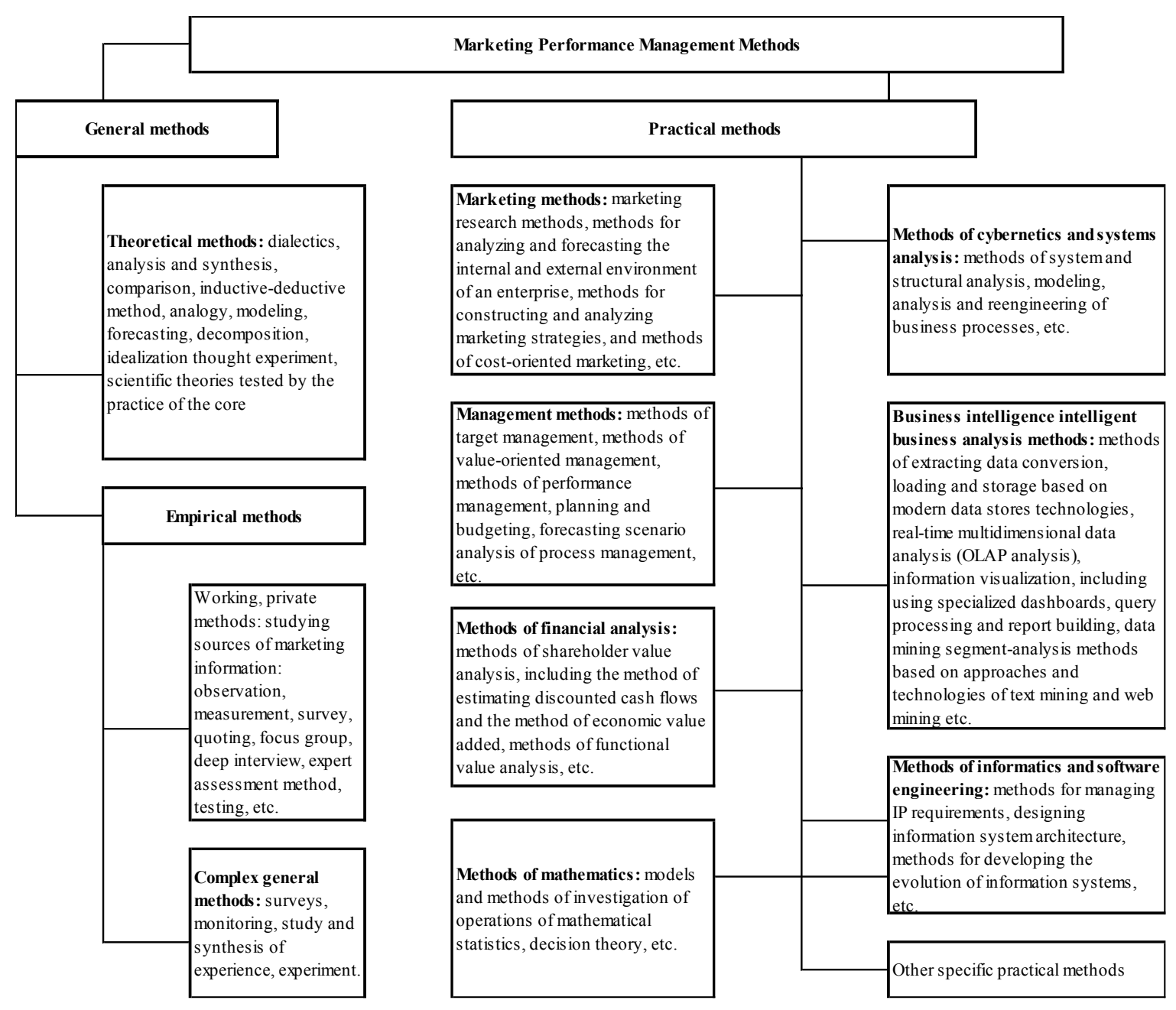

Fig. 3. Methods for managing the performance of marketing [6]

systems of various classes: CPM, Business Intelligence, ERP, CRM and others; mathematical models and methods for solving problems of target planning, forecasting, data mining, decision support; other means.

The main processes of marketing performance management include: modeling, forecasting, processoriented planning, budgeting, consolidation, reporting and analysis, functional cost analysis, scoring card analysis and adjustment of key parameters in accordance with the results achieved, etc. is the successful implementation of a marketing strategy and the improvement of marketing management activities based on well-designed and a properly functioning marketing performance management system.

\section{Features, conditions, norms and principles}

Features of marketing performance management include the following: uniqueness, determined by the unique combination of the internal and external environment of the enterprise (firms, companies); adaptability, ability of goal setting and self-organization; market orientation; influence of corporate culture and management practices and business processes that have developed in the firm; the constant need for change due to the rapidly changing of external environment and the development of technologies; the holistic nature of the activities covering all aspects of the firm's work in the market; features associated with the characteristics of a transitive economy, the characteristics of the activities in the electronic market on the Internet. The conditions for marketing performance management include motivational, personnel, logistic, scientifically-methodical, organizational, financial, regulatory and informational conditions, determined to a large extent by the specifics of the company, all external and internal environment, the specifics of a particular industry, to which includes the company, etc.

The standards for marketing performance management include both general and specific norms. These are legal norms determined by the current legislation in the field of trade, marketing and advertising, information, etc. Also these are the norms of professional ethics of employees engaged in this activity: the most important standard here is the timely provision of reliable information necessary 
for calculating performance indicators.

Logic and methodological systematization and selection of the basic principles of marketing performance management was carried out. The principles of marketing performance management, specifying the strategy, goals of behavior, valueoriented, taking into account the direction and predicted activity of the company, include: the principle of compliance of the marketing performance management system in the marketing management system, goals, objectives and capabilities of the company; the principle of orientation of the marketing strategy to increase the shareholder value of the company; the principle of targeted marketing management based on the description of the marketing strategy in the form of a balanced, complete and internally consistent system of goals, key indicators and strategic measures within the framework of the overall strategy of the company.

The governing principles of marketing performance management, which determine the strategic behavior of a company in terms of risk and uncertainty, include: the principle of integrity of the marketing performance management system, the principle of integrating the marketing performance management system with the marketing management system, corporate performance management system and corporate information system; information relevance principle; the principle of closed loop feedback management, which includes long-term and operational planning, modeling and forecasting, analysis, monitoring performance indicators and adjusting goals in the context of the overall strategy of the company; the principle of a systematic hierarchical structure of indicators efficiently, their reasonable sufficiency, measurability and transparency; the principle of analyzing the main observable indicators (indicators) of the external environment within the framework of the general system of performance indicators. The principles of performance management marketing in the field of tactical analysis and design activities of the company include: the principle of regular monitoring and control of key performance indicators and indicators

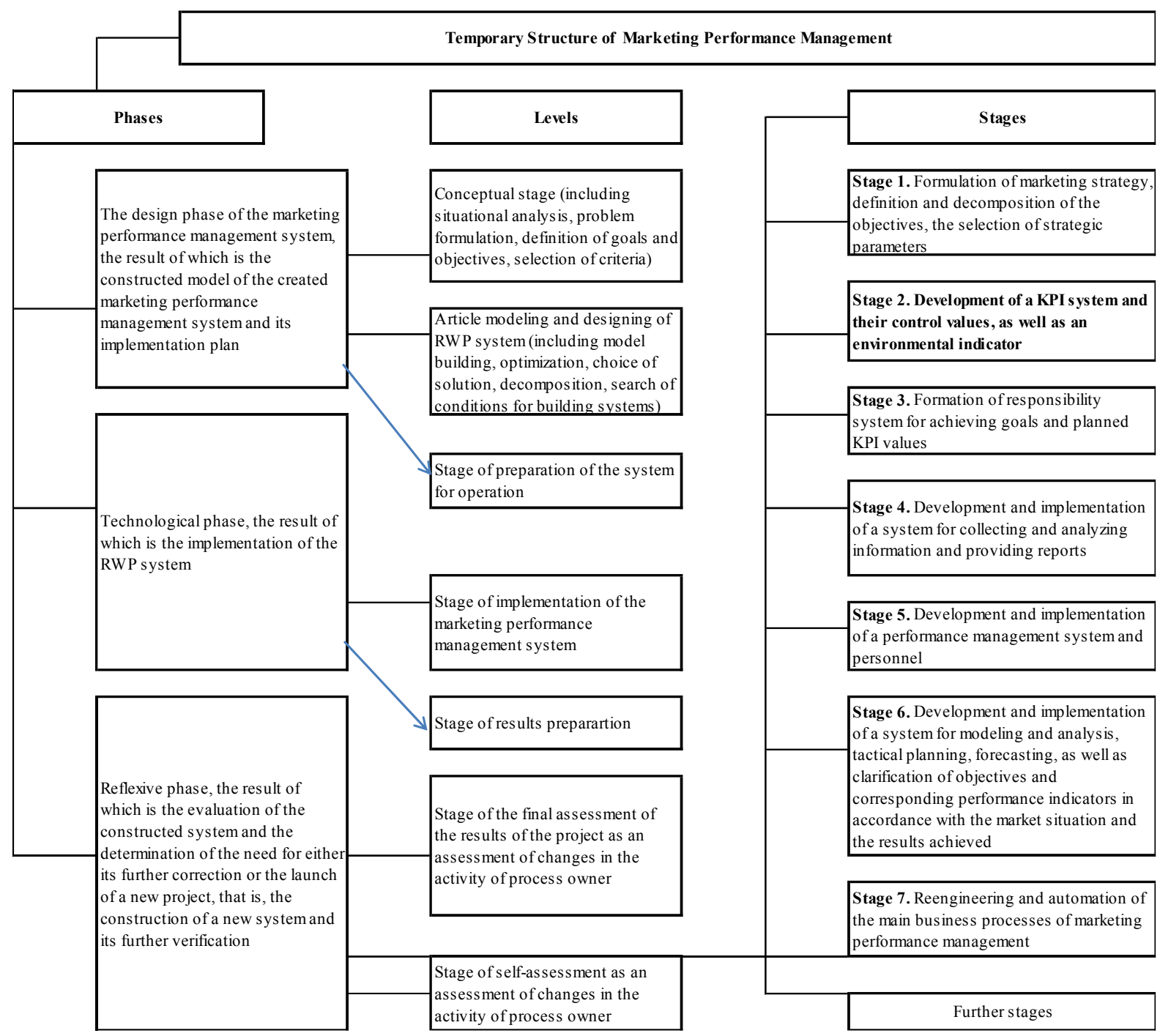

Fig. 4. Temporary Structure of Marketing Performance Management 
(indicators) of the external environment and the corresponding adjustment of plans and actions of the company in the market; the principle of competence management and staff motivation within the overall system of target management.

The marketing performance management system is a holistic multi-level system that is part of the marketing management system and corporate performance management system; it focuses on targeted management and marketing strategy implementation, has monitoring, control and feedback capabilities and uses the capabilities of an integrated marketing information system, providing an integrated and continuous approach to the marketing management process. The temporal structure of management of effective marketing performance in the conditions of spatial-market relations is presented in Fig. 4 and 6 (includes stages and levels):

The authors identify and analyze the main stages of designing a marketing performance management system using the following marketing competencies, including the following factors:

- formalization of the marketing strategy in the form of a system of interrelated measurable goals, taking into account their decomposition, highlighting strategic initiatives;

- development of a system of key performance indicators (Key Performance Indicators, KPI) and their control values, as well as environmental indicators reflecting the company's position on the market;

- formation and implementation of a system of responsibility for achieving the goals and planned values of KPI and the associated system of personnel motivation;

- development and implementation of systems for collecting and analyzing information and reporting;

- development and implementation of staff performance management system;

- development and implementation of a system for modeling and analysis, tactical planning, forecasting, as well as clarification of objectives and corresponding performance indicators in accordance with the market situation and the results achieved;

- reengineering and automation of the main business processes of marketing performance management.

\section{Findings}

At the beginning of the 21-st century, the geoeconomic space began to move: It pushed aside geopolitics and geostrategy. For many states, the geoeconomic approach is central for the formation of a national and regional strategy in the external arena. Within the framework of the geo-economic space itself, there is an acceleration of processes associated with the layout of the framework of world economic relations.

National regional economies as integral parts of the global system, as well as their models and tools of spatial interaction, cannot but respond to the profound changes occurring in the depths of the post-industrial model, where a new civilized model of development is born which is the neo-economic.

The work shows that in order to clarify the sources of changes observed in the national regional framework in many areas it seems necessary to reassess views on the processes taking place, that is, a new system of methodological approaches is needed. In terms of further research on this issue, the work examined the effectiveness of marketing and the development of marketing competence from the standpoint of creating conditions for improving the efficiency of spatial interaction.

According to the results obtained in the study, it became clear that current and practically important for enterprises (firms, companies) are approaches to designing a marketing performance management system, which include methods for identifying measurable strategic goals and key performance indicators that reflect a holistic marketing strategy. also the effectiveness of the information infrastructure of the market entity.

It is substantiated that marketing strategies within the framework of the process of spatial interaction in a global economy are aimed at identifying market opportunities and developing growth strategies, as well as developing marketing competencies as a basic tool for implementing strategies for achieving sustainable relationships with target groups of consumers.

The work proposes an approach to the methodology of managing effective marketing using the provisions of marketing competence for the conditions of the process of spatial interaction, which will contribute to more effective integration of Ukrainian enterprises in the framework of the new civilizational development model which is called new-economic.

\section{REFERENCES}

1. Bagiev L.G., Meffert H. (2009). Marketinh vzaymodeistvyia: kontseptsyia, stratehyia, effektyvnost. [Marketing Interaction: Concept, Strategy, Efficiency]. St. Petersburg: Publishing house of St. Petersburg State University of Economics and Finance, 342 p., [in Russian].

2. Bagiev L.G. (2012). Marketinh vzaimodeystviya: Uchebnik dlya magistrov [Marketing Interaction: A Textbook for Masters]. St. Petersburg: Publishing house of St. Petersburg State University of Economics and Finance, 410 p., [in Russian].

3. Solovyova Y.N. (2015). Razvitie marketingovoy kompetentnosti kak faktor povyisheniya effektivnosti prostranstvennogo vzaimodeystviya. Problemy sovremennoy 
ekonomiki [The development of marketing competence as a factor of improving the efficiency of spatial interaction. Problems of the modern economy]. No. 4 (56) pp. 288-290, [in Russian].

4. Bagiev L.G., Pinchuk A.V. Serova E.V. Shulga A.O. (2012). K voprosu formirovaniya kontseptsii marketinga prostranstvennogo vzaimodeystviya. Problemy sovremennoy ekonomiki [On the formation of the marketing concept of spatial interaction. Problems of the modern economy], No. 4. pp. 219224 [in Russian].

5. Bagiev L.G. (2014). Formirovanie kontseptsii marketinga prostranstvennogo vzaimodeystviya. Korporativnoe upravlenie i innovatsionnoe razvitie ekonomiki Severa. [Formation of the concept of spatial interaction marketing. Corporate governance and innovative development of the economy of the North]. St. Petersburg: No. 1. pp.3-14.

6. Kitova O.V. (2012). Kontseptsii i informatsionnaya infrastruktura obespecheniya upravleniya rezultativnostyu marketinga, teoriya i metodologiya [Concepts and information infrastructure to ensure the management of marketing performance, theory and methodology]: Dis. Doctor of Economics: 08.00.05 Kitova Olga Viktorovna. M. 2012. - 326 p.

Received 18.10.2018

Reviewer: Dr.e.s., prof. Tkachenko A.M.

\section{ЕФЕКТИВНІСТЬ МАРКЕТИНГУ ТА РОЗВИТОК МАРКЕТИНГОВОЇ КОМПЕТЕНЦІЇ ЯК ФАКТОР ПІДВИЩЕННЯ ЕФЕКТИВНОСТІ ПРОСТОРОВОЇ ВЗАЕМОДІї}

Дубницький В.І., Кожевник Ю.В., Доценко А.С.

В роботі розкрито зміст маркетингової компетенції як основи концепції забезпечення управління результативним маркетингом, а також як основи створення стійкої конкурентної переваги, виходячи з положень парадигми Г. Багієва і Х. Хоккансона - концепції маркетингу просторової взаємодії. Показані складові і джерела залучення додаткової маркетингової компетенції. Зроблене уточнення, що в глобальному інформаиійному суспільстві концепиії управління маркетингом в умовах глобальної економіки розвиваються в тісній взаємодії з сучасними концепціями і підходами в сфері менеджменту, маркетингу, фінансового аналізу, системного аналізу, інформатики та моделювання економічних процесів геоекономічного простору. За результатами роботи отримали розвиток положення методології системи управління результативністю маркетингу. Наведена ілюстративна модель «Джерела придбання додаткової маркетингової компетенції», а також удосконалення кониепт-моделі Ю.М. Соловйової «Взаємозумовленість компонентів маркетингової компетенції».

Ключові слова: маркетинг, маркетинг просторової взаємодії, компетентність, маркетингова компетентність.

\section{ЭФФЕКТИВНОСТЬ МАРКЕТИНГА И РАЗВИТИЕ МАРКЕТИНГОВОЙ КОМПЕТЕНЦИИ КАК ФАКТОР ПОВЫШЕНИЯ ЭФФЕКТИВНОСТИ ПРОСТРАНСТВЕННОГО ВЗАИМОДЕЙСТВИЯ}

Дубницкий В.И., Кожевник Ю.В., Доценко А.Е.

В работе раскрыто содержание маркетинговой компетенции как основы концепции обеспечения управления результативным маркетингом, а также как основы создания устойчивого конкурентного преимущества исходя из положений парадигмы Г. Багиева и Х. Хоккансона - концепцию маркетинга пространственного взаимодействия. Показаны составляющие и источники привлечения дополнительной маркетинговой компетенции. Уточнено, что в глобальном информационном обществе концепции управления маркетингом в условиях глобальной экономики развиваются в тесном взаимодействии с современными концепииями и подходами в сфере менеджмента, маркетинга, финансового анализа, системного анализа, информатики и моделирования экономических процессов геоэкономического пространства. По результатам работы получили развитие положения методологии системы управления результативностью маркетинга. Приведена иллюстративная модель «Источники приобретения дополнительной маркетинговой компетениии», а также усовершенствование концептмодели Ю.Н. Соловьёвой «Взаимообусловленность компонентов маркетинговой компетенции.

Ключевые слова: маркетинг, маркетинг пространственного взаимодействия, компетентность, маркетинговая компетентность. 